\title{
Intelligent or smart cities and buildings: a critical exposition and a way forward
}

Article

Accepted Version

Ghaffarianhoseini, A., AlWaer, H., Ghaffarianhoseini, A., Clements-Croome, D., Berardi, U., Raahemifar, K. and Tookey, J. (2018) Intelligent or smart cities and buildings: a critical exposition and a way forward. Intelligent Buildings International Journal, 10 (2). pp. 122-129. ISSN 1750-8975 doi: https://doi.org/10.1080/17508975.2017.1394810 Available at https://centaur.reading.ac.uk/74501/

It is advisable to refer to the publisher's version if you intend to cite from the work. See Guidance on citing.

Published version at: https://doi.org/10.1080/17508975.2017.1394810

To link to this article DOI: http://dx.doi.org/10.1080/17508975.2017.1394810

Publisher: Taylor \& Francis

All outputs in CentAUR are protected by Intellectual Property Rights law, including copyright law. Copyright and IPR is retained by the creators or other copyright holders. Terms and conditions for use of this material are defined in the End User Agreement.

www.reading.ac.uk/centaur 
Central Archive at the University of Reading

Reading's research outputs online 


\title{
Intelligent or smart cities and buildings: a critical exposition and a way forward
}

\author{
Amirhosein Ghaffarianhoseini ${ }^{\mathrm{a}}$, Husam AlWaer ${ }^{\mathrm{b}}$, Ali Ghaffarianhoseini ${ }^{\mathrm{a}}$, \\ Derek Clements-Croome ${ }^{\mathrm{c}}$, Umberto Berardi ${ }^{\mathrm{d}}$, Kaamran Raahemifar ${ }^{\mathrm{d}}$ and \\ John Tookey ${ }^{\mathrm{a}}$ \\ ${ }^{a}$ Department of BuiltEnvironmentEngineering, Auckland University of Technology (AUT), Auckland, New \\ Zealand; ${ }^{b}$ School of SocialSciences (Architecture \& Planning), University of Dundee, Dundee, UK; \\ ${ }^{\mathrm{c}}$ School of theBuilt Environment, University of Reading, Reading, UK; ${ }^{\mathrm{d}}$ Faculty of Engineering and \\ Architectural Science, Ryerson University, Toronto, Canada
}

CONTACT: Amirhosein Ghaffarianhoseini; amirhosein_ghaffarian_hoseini@yahoo.com

\begin{abstract}
In the last decade, there has been an undoubtedly rising interest in the field of intelligent and smart built environments from design and construction to management, operational and governance perspectives. These recent endeavors, observed at both academic and professional levels, can be classified into city, neighborhood and building scales. In this context, understanding what we really mean by the word intelligent and smart is crucially important. This technical note attempts to clarify and further explore how intelligence differs from smartness in this context. Having intelligence as the main umbrella embracing other interrelated smart subsets is one way of thinking as supported by previous debates, while there are also other lines of thinking with more preference on the smartness as the core concept.
\end{abstract}

KEYWORDS: intelligent buildings; smart buildings; intelligent cities; smart cities; built environment

In the last decade, there has been an undoubtedly rising interest in the field of intelligent and smart built environments from design and construction to management, operational and governance perspectives. These recent endeavors, observed at both academic and professional levels, can be classified into city, neighborhood and building scales. In this context, understanding what we really mean by the word intelligent and smart is crucially important. This technical note attempts to clarify and further explore how intelligence differs from smartness in this context. Having intelligence as the main umbrella embracing other interrelated smart subsets is one way of thinking as supported by previous debates (Gardner 2000; Clements-Croome 2013; Derek $\&$ Clements-Croome 1997), while there are also other lines of thinking with more preference on the smartness as the core concept. 
From a large-scale point of view, it can be inferred that there is a relatively wide consensus about the use of 'smart cities' as the core concept instead of 'intelligent cities'. Nevertheless, the primary question of what we mean by a smart city is yet to be fully answered despite a surprisingly high number of research investigations in this field. A decade ago, Hollands (2008) critically looked at the notion of smart cities and criticized labeling cities as smart without an availability of a universal definition for them or a common understanding for their essence and key performance indicators. While in general, smart means using enabling technology to provide seamless connectivity between systems and support personalization, from the era of Hollands (2008) until now, this definition has continuously undergone an evolutionary change.

Along this way, further exploring the smart cities, Walters (2011) referred to the incorporation of physical and virtual worlds and place-based information planning. Lombardi et al. (2012) elucidated a new way of analyzing the performance of smart cities through a developed model encompassing all key performance indicators and structuring an analytic network process. Roche et al. (2012) critically investigated the smartness of smart cities and argued that our future cities should embrace spatially enabled citizens and context-aware urban built environments that can intelligently sense, actuate and respond. Deakin and Al Waer (2012) clearly highlighted a transition from intelligent to smart cities with a predominant focus on addressing the needs of market and users rather than the intelligence itself. Similarly, Deakin $(2011,2013)$ continued to portray this transition to smart cities from a more comprehensive approach via having intelligence as the embedded component of future cities. In both attempts, they looked at intelligence as a driving force and an enabler for achieving a smart city while arguing that an internationally accepted definition of smart cities is yet to come. In this line, various researchers attempted to develop new frameworks and definitions for smart cities: Albino, Berardi, and Dangelico (2015) examined the existing definitions realizing the multi-faceted essence of smart cities and claiming that smart cities' spirit is moving beyond information and communications technology (ICT). Lehmann (2016) attempted to clarify the concept of smart city, referred to New Songdo City in South Korea and Singapore as the relevant examples, and suggested to look at the success of Freiburg, Copenhagen and Singapore as a result of the incorporation of green, sustainable and smart models. Similarly, Di Silvestre (2017) explored a holistic perception about smart cities while Monfaredzadeh and Berardi (2015) and more recently Ahvenniemi et al. (2017) compared the sustainable and smart city assessment frameworks with the aim of clarifying the confusion between smart and sustainable cities, and showed that a significant distance between these two metrics exists. Along this way, Mosannenzadeh et al. (2017) explore the significance of smart energy city (SEC) as a novel energy-oriented 
emerging approach in Europe.

Though it can be seen that in recent years, numerous studies have been focusing on setting clear dimensions and developing detailed or broader visions of smart cities to tackle the existing confusion, the upcoming studies continue re-defining the essence of smart cities and re-developing new models or lists of indicators. While to some extent, this is inevitable and can be contributive due to the broad horizon and multi-faceted attributes of smart cities as well as their possible unexplored potentials, the ever-continuing search for such definition or model will be replaced by drawing more attention to the enhancement of the existing models and frameworks.

From a smaller scale viewpoint, looking at buildings, there has been even more confusion about the interchangeably used terms such as intelligent, smart and sustainable buildings. While to some extent, green and sustainable buildings, as the main output of green building councils around the world, can embrace the majority of the interchangeably used terms based on their ambitious targets to cover environmental, social and economic dimensions of sustainability as portrayed in LEED, BREEAM and now WELL, intelligent and smart building features have been less considered as an inherent part of their scope. The idea of intelligent and smart buildings may seem new but its history goes back to years ago. Back in1997, Clements-Croome developed a holistic definition of intelligent buildings and clarified what it should encompass. Hartkopf et al. (1997) similarly attempted to define the intelligent buildings and showcased the features of an intelligent workplace at Carnegie Mellon University. Wong et al. (2005) argued that there is a need for more systematic frameworks to define intelligent buildings. Responding to the raised needs, Alwaer and Clements-Croome (2010) identified and assessed the key performance indicators of intelligent buildings. With the rapidly growing importance of green buildings, Clements-Croome (2011) drew more attention to the neglected features of intelligent buildings and claimed they should be more sustainable, healthier and dedicated to people.

On the contrary, other researchers tend to promote smart buildings: Wang et al. (2012), Zhang, Shah, and Papageorgiou (2013) and Rocha, Siddiqui, and Stadler (2015) explored and proposed effective energy management strategies for smart buildings; McGlinn et al. (2010) recommended an innovative tool to assess smart building applications; and Joustra and Yeh (2014) looked at water cycle management in smart buildings. In addition, various universities took initiatives to develop smart homes as living labs, as reviewed by GhaffarianHoseini et al. (2013). In particular, once it comes to residential environments, the term 'smart' has been highly utilized making it a common label for highly automated and ICT-integrated homes. In this line, Harper (2006) comprehensively looked into the current and future of smart homes; GhaffarianHoseini et al. (2013) put forward what future smart homes should 
look like and compared several existing case studies. More recently, Strengers (2016) explored the potentials and future of smart homes from new perspectives and Suryadevara et al. (2013) evaluated the potentials of smart homes for protecting elderlies and determining their health status.

To the best knowledge of the authors, despite the significant number of technical studies on smart buildings and their performance, a relatively small number of researchers have attempted to define smart buildings compared to the attempts for clarifying intelligent buildings. Among those, in 1994, Drewer and Gann introduced smart buildings, defined them and showed their benefits. Their definition was purely related to the integration of state-of-the-art technologies and advanced services. More recently, Buckman, Mayfield, and Beck (2014) proposed a more comprehensive definition of smart buildings and concluded that

Smart Buildings are buildings which integrate and account for intelligence, enterprise, control, and materials and construction as an entire building system, with adaptability, not reactivity, at its core, in order to meet the drivers for building progression: energy and efficiency, longevity, and comfort and satisfaction. (98)

The definition proposed by Buckman et al. (2014) was in line with their previous study (Buckman et al., 2013) where they similarly looked at intelligence as one of the four components of smart buildings: control, enterprise, materials and design, and intelligence. Nevertheless, ClementsCroome (2013) described intelligent buildings as having three main components:

- Smart quality enabled by a range of evolving digital technologies;

- Sentient quality so the city or building responds to physical, social and mental well-being;

- Sustainability covering the application of green technologies to enable the efficient and economic use of resources like energy, water and waste.

In a more recent investigation, Ghaffarianhoseini et al. (2015) presented the intelligent buildings as a focal point embracing green, sustainable, smart and other related attributes. According to their proposed definition, smartness was only an indicator of intelligent buildings. Based on their analysis, intelligent buildings should be designed and developed according to four key performance indicators: smartness and technology awareness, economic and cost efficiency, personal and social sensitivity, and environmental responsiveness. In addition, Turner (2016) investigated the real meaning of 
intelligent buildings through referring back to the essence of intelligence and proposed drawing more attention to the emergent intelligence than the executive intelligence. On the other side, Kuo et al. (2017) utilized the term 'intelligent green' building and explored their related policies towards meeting the targets of the recent climate change conference (COP 21). Lilis et al. (2016) studied the future of intelligent buildings and similarly showed they are moving beyond building automation. Their vision of intelligent buildings was in line with the rapid manifestation of emerging technologies as they envisaged that future intelligent buildings will be inherently intertwined with the internet of things (IoT) and people centered design. To sum up, intelligent buildings are designed to embrace these fundamental roles: addressing users' requirement in functional and sensory needs; utilizing smart technology to enable security and monitoring to aid facilities management; being sustainable with viewpoints to energy, water and waste through incorporation of smart and appropriate green passive and active environmental design. Likewise, buildings of future, as suggested by Heidari et al. (2017), should draw more realistic attention to the health and well-being status of their occupants. Hence, development of healthy buildings as part of a healthy city is another fundamental direction of the eventual impacts of the integration of design intelligence and smart components into the future built environments (Figure 1).

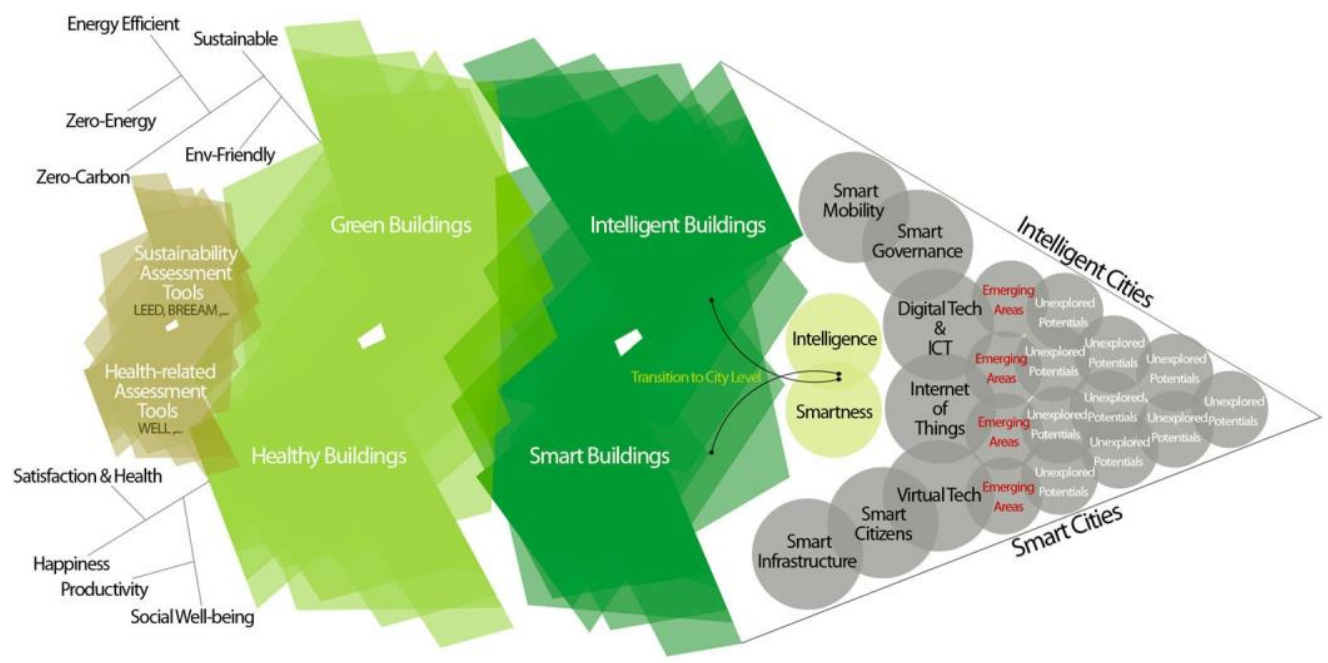

Figure 1. Clarifying the overview of intelligent and smart buildings and cities concept. 
On the other side, regardless of the cities and buildings being called intelligent or smart, there is a great need for robust commitment at a broad governance level towards ensuring more effective stakeholders' involvement in all phases. Governance of intelligent or smart cities and buildings is not only restricted to what governments implement and instead, it has to be shaped based on interactions among various-sized enterprises, non-governmental organizations (NGOs) and local governments while this process needs more efficient involvement of citizens in decision-making (Bolívar 2015). In the same line, looking at intelligent or smart urban governance, Mostashari et al. (2011) state that 'In a cognitive city, the citizen becomes an active element of urban governance, not only through civic participation, but also through serving as a sensor for the operational state of the urban infrastructure'. New modes of governance structures in this context require both private and institutional partnerships, involvement and sponsorships towards promoting e-governance, ICT-enabled governance and real-time governance while developing more insightful strategic planning (Misuraca, Broster, and Centeno 2012; AlWaer, Bickerton, and Kirk 2014; Ojasalo and Tähtinen 2017). From a broad perspective, such governance embraces four key models: governmentto- government, government-to-citizens, government-to-business and government-to-employees (Raj and Raman 2015). Furthermore, there is also a need for a responsive governance-based spirit across the whole supply chain from conceptualization, planning, design, and construction to monitoring, facilities management, commissioning, and post-occupancy evaluation. In fact, the underpinning political motivations of 'smart', and by extension 'intelligent' can also play an influential role in defining a more clarified intelligent/smart conceptual model for future implementations.

This study presents the paradoxical definitions and frameworks of intelligent and smart cities and buildings. The analysis demonstrates that the two terms are complementary, once their essence is correctly interpreted with a mutual aim to use their ever-growing potentials to optimize the performance and impacts of buildings and cities.

While from one point of view, the interchangeable use of the terms intelligent or smart may not matter and/or be insignificant to community, from another perceptive direction, a lack of clarity can lead to further confusion for the professionals and related stakeholders. From Gardner (2000)'s viewpoint on intelligence to the recent critiques on intelligent buildings, it should be remembered that 'intelligent' is a broader and more holistic term than 'smart', both linguistically and technically. Recent studies articulate about artificial intelligence embracing smart components or they debate about intelligent minds rather than smart minds. Elements of buildings, urban contexts or cities can be smart in order to enable their embedded systems to function effectively (i.e. smart cars; smart phones and smart watches) but the whole building or 
city has to be intelligent. In line with what discussed, Wang et al. (2016) remind that a smart city performs once it is comprised of intelligent architecture. Their analysis concludes that 'The city is inseparable from architecture, and the intelligent buildings are indispensable for the smart city'. It is believed that the intelligent-smart debate will continue but using the present literature allows strengthening the existing frameworks and conceptual models to shed more lights on the real essence and future directions of building and cities. There is no doubt that in the twenty-first century, there has been a radical two-way transition from sustainability to intelligence and smartness. Buildings and cities need to be much more than only intelligent or smart. However, while in this context, the prioritized agenda should be paving the way towards creating better living environments for people irrespective of what they would be called (intelligent or smart), the existing scenarios and the interchangeable use of the above terms can lead to confusion and uncertainty. Moving beyond the current level of debates, as extensively discussed by Greenfield (2017), we should continue to explore how such advanced datadriven technologies, IoT devices and their radical adoption can provide meaningful benefits for individuals, societies and our environments, what impacts they have on daily lifestyles, who benefits from these enormous sources of data, how new challenges are being created and how the real essence of human is being redefined.

\section{Disclosure statement}

No potential conflict of interest was reported by the authors.

\section{Notes on contributor}

Dr Amirhosein Ghaffarianhoseini is an architect, an urban thinker and a lecturer in architectural engineering and building science at Auckland University of Technology, New Zealand. With over 8 years of academic teaching and research experience in New Zealand, Canada and Malaysia in the context of sustainable built environments, his research primarily concentrates on the future of buildings, urban areas and cities. He is also an adjunct research faculty at University of Malaya in Kuala Lumpur, Malaysia. He has completed his postdoctorate in advanced architectural sustainability at Ryerson University in Toronto, Canada. He was a senior lecturer in architecture and urban sustainability at the University of Malaya (UM) for over 2 years and a senior lecturer in architecture for over 4 years, as well as a programme leader for BSc Arch \& BArch for 1 year, at Limkokwing University. Besides his academic experience, he has served as a practicing architectural designer. His research \& practice bring together architectural design, healthy buildings, 
urban climate, and sustainable development. He is a founding director of Responsive + Green Urban Built Environment (R+G UBE) Lab which is an interdisciplinary research group based in New Zealand, Malaysia and Canada (www.rgube.com). He is currently supervising over $10 \mathrm{PhD} / \mathrm{MSc} / \mathrm{MArch}$ candidates and RAs. Dr. Amir has led various nationally/internationally funded research projects. His research predominantly focuses on four core areas of architectural design, building science, green building technology, and urban modelling. He has a body of funded research comprising over NZ\$ $300,000.00$. He mainly teaches final-year courses in the areas of architectural design, building performance evaluation and urban sustainability. He has coordinated design studios at both undergraduate and postgraduate levels, focusing on integrated design, building science and sustainability. He is an associate editor of Intelligent Buildings International while serving as editorial board member, scientific/technical committee member and reviewer for many top-ranked international journals and conferences. His publications have received over 800 citations in Google Scholar.

Dr Husam AlWaer is an URBANIST with a background in architecture, urban planning and sustainability, who writes intensively and speaks regularly on making better places. He is a Senior Lecturer in Sustainable Urban Design and Evaluation in the School of Social Sciences (Architecture + Urban Planning), University of Dundee, having previously researched and taught at Reading and Liverpool universities. Husam's work has had a demonstrable impact in academia as well as on practice. He has a passionate interest in the future of sustainable/intelligent places, towns and buildings, in particular, the development of new thinking on processes and methods to unlock sustainable urbanism. Husam has gained recognition for providing intellectual leadership in sustainable place making and master planning, contributing to emerging theory, practice and technical developments. This is evidenced by his contribution to the Scottish Government's Planning Review (with Kevin Murray Associates); a recent invitation by the Scottish Government, Architecture and Planning Unit to sit on their expert panel to assess a range of 'charrette' and 'activating ideas' funding; and a recent invitation by the RTPI East Scotland Chapter to join their committee. Also, his 'thought leadership' contributions have included presentations/workshops to national and international organisations, firms and governments including the United Nations Programme for Human Settlements III, PlaceMaking Leadership Forum, Scottish Government, Saudi Government, RTPI Scotland, Urban Design London, and Urban Design Group. He has published over 35 peerreviewed international journal papers, professional reports and books relating to the broad topic of Urban Design, Spatial Planning and Sustainability, including his recent published book "Site and Composition: Design Strategies in Architecture and Urbanism" with Bandyopadhyay and Aldallal (Routledge, 2016), and a new international edited book with Barbara Illsley on "Rethinking 
Masterplanning: Creating Better Places" (ICE Publisher, June 2017). He was awarded both the 2014 and 2016 Reed and Mallik Ltd Journal Prize for the best paper published in the Journal of Urban Design and Planning.

Dr Ali Ghaffarianhoseini(PhD, MSc \& BSc) is a lecturer (Auckland University of Technology, New Zealand), and a professional architectural designer (NZIA Academic Member) holding $\mathrm{PhD}$ and $\mathrm{MSc}$ degrees in Architectural Studies and BSc in Architecture Engineering. He is a founding director of Responsive + Green Urban Built Environment Lab, New Zealand (www.rgube.com). His research has so far been cited by over 800 articles. In conjunction with teaching Architecture Engineering and Construction Engineering courses, Ali is an active researcher focusing on Building Information Modelling (BIM), Design Cognition \& Computing; Building Automation Systems, Smart Homes \& Intelligent Buildings, Sustainable Design Developments, Green Buildings and Integrated Design Studies. He is the sole representative of AUT at the New Zealand National BIM Education Working Group. He has been diligently engaged in various international research collaborations with world-class academicians from Australia, Canada, France, Hong Kong, Iran, Malaysia, New Zealand, South Korea, UK, USA, etc., and has achieved well-recognized international innovation awards plus scholarship of over 90 international level patents; journal articles; books/book chapters; conference papers, etc. His research contribution resulted in publication of many highly read and cited papers in high impact factor international journals, namely Building and Environment, Cities, Applied Energy, Renewable \& Sustainable Energy Reviews, Sustainable Cities $\mathcal{E}$ Society, Urban Forestry \& Urban Greening, Intelligent Buildings International, Architectural Science Review, etc. Throughout his academic career, Ali has developed, moderated, reviewed and contributed to accreditation of various academic programmes and contents concerning architecture and the built environment engineering as a whole along with developing \& facilitating special research, teaching and testing laboratories. Ali is currently supervising $12 \mathrm{PhD}$ candidates besides supervising 15 , graduating 28 and orally examining more than 70 Master's students. He has been a key member of scientific/technical committees for international academic conferences in many countries.

Professor Derek Clements-Croome at Reading University has worked in the building design and contracting industry before entering university life. He has just been appointed a Visiting Professor at Queen Mary University London. He has founded and directed courses including a BSc in building environmental engineering at Loughborough University in 1970 and an interdisciplinary Government funded MSc in Intelligent Buildings at Reading University in 1996 covering design, management and operation. He has also worked in architecture and building engineering at the University of Bath (1978-1988). 
He now offers strategic advice to clients, designers and facilities managers on attaining and managing healthy and sustainable environments in buildings of all types. He researches, writes and lectures on these issues for companies and wider audiences nationally and internationally in China, Australia, New Zealand, South Africa, Poland and Finland particularly. Some of his books have been published in Chinese and Russian. He edits and founded the Intelligent Buildings International first journal published by Taylor and Francis. His research

includes an EPSRC 3-year project which showed the effects of $\mathrm{CO} 2$ on children's learning in primary schools. Now his work is directed at the health, well-being and the impact of wearable technology in the workplace. He works closely with the British Council for Offices in applying the research. Currently working with the British Council of Offices on Health and Well-being in buildings and the use of wearables in the workplace. Derek is a Commissioner on air quality and also biodiversity for the Boroughs of Hammersmith-Fulham and for the Zerofifty Commission for Haringey. He is also Building Environmental Expert for the CABE arm of the Design Council; a Fellow of BRE Academy. He was a member of the UK Green Building Council team who wrote the Report Health and Wellbeing in Homes double- dash;-July 2016 and the World Green Council Report on Health and Wellbeing in Offices 2014. He has edited and written chapters in the 3rd Edition of the book Creating the Productive Workplace was published by Routledge in 2017. It is $95 \%$ new.

Dr Umberto Berardi is an Associate Professor at Ryerson University, in Toronto (Ontario, Canada). His main research interests are related to the study of building systems that incorporate new materials for improved performance. Dr Berardi has a body of funded research comprising over $\$ 1.4 \mathrm{M}$ in government and private sector-sponsored research. Dr Berardi contributes to several academic and scientific communities, acting as editor-in-chief, associate editor, and editorial board member of several journals.

Professor Kaamran Raahemifar received his B.Sc. degree (1985-1988) in Electrical Engineering from Sharif University of Technology, Tehran, Iran, his MASc. degree (1991-1993) from Electrical and Computer Engineering Dept., Waterloo University, Waterloo, Ontario, Canada, and his Ph.D. degree (19961999) from Windsor University, Ontario, Canada. He was Chief Scientist (1999-2000), in Electronic Workbench, Toronto, Ontario, Canada. He joined Ryerson University in Sept. 1999 and was tenured in 2001. Since 2011, he has been a Professor with the Department of Electrical and Computer Engineering, Ryerson University. He is the recipient of ELCE-GSA Professor of the Year Award (Elected by Graduate Student's body, 2010), Faculty of Engineering, Architecture, and Science Best Teaching Award (Apr. 2011), and Department of Electrical and Computer Engineering Best Teaching Award (Dec. 2011), and Research Award (Dec. 2014). He has been awarded more than $\$ 6 \mathrm{M}$ 
external research fund during his time at Ryerson.

His research interests include: 1) Optimization in Engineering: Theory and Application, which includes grid optimization and net-zero communities, as well as biomedical signal and image processing techniques, 2) Big Data Analysis (Dictionary/Sparse Representations, Interpolation, Predictions), 3) Modelling, Simulation, Design, and Testing, and 4) Time-Based Operational Circuit designs.

Professor John Tookey graduated with a $\mathrm{PhD}$ in Industrial Engineering from the University of Bradford in 1998. Since then he has had a wide range of experience activing as a research fellow, lecturer, senior lecturer, associate professor and later as a fully professor. His career has spanned teaching and research experience covering the UK, South Africa, Australia and New Zealand. Academically, he has introduced numerous undergraduate and postgraduate degree programmes in the built environment. His research has developed in parallel, publishing widely around supply chain management, construction logistics, building performance and related areas. Later, Professor Tookey was appointed as a Science Leader in the National Science Challenge 11 "Building Better Homes Towns and Cities" project seeking to establish at a New Zealand national level a construction industry that delivers a higher quality, more liveable and affordable built environment for the future.

ORCID

Umberto Berardi (Dhttp://orcid.org/0000-0002-0508-6195 


\section{References}

Ahvenniemi, H., A. Huovila, I. Pinto-Seppä, and M. Airaksinen. 2017. "What Are the Differences between Sustainable and Smart Cities?" Cities (London, England) 60: 234-245.

Albino, V., U. Berardi, and R. M. Dangelico. 2015. "Smart Cities: Definitions, Dimensions, Performance, and Initiatives." Journal of Urban Technology 22 (1): 3-21.

AlWaer, H., R. Bickerton, and R. D. Kirk. 2014. "Examining the Components Required for Assessing the Sustainability of Communities in the UK." Journal of Architectural and Planning Research 31 (1): $1-26$.

Alwaer, H., and D. J. Clements-Croome. 2010. "Key Performance Indicators (KPIs) and Priority Setting in Using the Multi- Attribute Approach for Assessing Sustainable Intelligent Buildings.” Building and Environment 45 (4): 799-807.

Bolívar, M. P. R. 2015. "Smart Cities: Big Cities, Complex Governance?" In Transforming City Governments for Successful Smart Cities, edited by Manuel Pedro Rodríguez-Bolívar, 1-7. Cham: Springer International.

Buckman, A. H., M. Mayfield, and S.B.M. Beck. 2014. "What Is a Smart Building?" Smart and Sustainable Built Environment 3 (2): 92-109.

Buckman, A. H., M. Mayfield, R. Meijer, and S. B. M. Beck. 2013. "Progressing from Intelligent to Smart Buildings." Proceedings of the 13th International Conference for Enhanced Building Operations, Montreal, Quebec, October 8-11.

Clements-Croome, D. 2011. "Sustainable Intelligent Buildings for People: A Review." Intelligent Buildings International 3 (2): 67-86.

Clements-Croome, D. J. 2013. Intelligent Buildings: Design, Management and Operation. $2 \mathrm{nd}$ ed. London: ICE.

Deakin, M. 2011. "The Embedded Intelligence of Smart Cities.” Intelligent Buildings International 3 (3): 189-197.

Deakin, M. 2013. Smart Cities: Governing, Modelling and Analysing the Transition. Abingdon: Routledge.

Deakin, M., and H. Al Waer, eds. 2012. From Intelligent to Smart Cities. Routledge.

Derek, T., and J. Clements-Croome. 1997. "What Do We Mean by Intelligent Buildings?" Automation in Construction 6 (5-6): 395-400.

Di Silvestre, M. L. 2017. “A Holistic Vision of Smart Cities: An Opportunity for a Big Change.” In Smart Cities Atlas, edited by Eleonora Riva Sanseverino, Raffaella Riva Sanseverino, and Valentina Vaccaro, 249-256. Cham: Springer International.

Gardner, H. E. 2000. Intelligence Reframed: Multiple Int. New York, NY: Perseus Books Group.

Ghaffarianhoseini, A., U. Berardi, H. AlWaer, S. Chang, E. Halawa, A. Ghaffarianhoseini, and D. Clements-Croome. 2015. "What is an Intelligent Building? Analysis of Recent Interpretations from an International Perspective." Architectural Science Review 59 (5): 1-20.

GhaffarianHoseini, A., N. D. Dahlan, U. Berardi, A. GhaffarianHoseini, and N. Makaremi. 2013. "The Essence of Future Smart Houses: From Embedding ICT to Adapting to Sustainability Principles." Renewable and Sustainable Energy Reviews 24: 593-607.

Greenfield, A. 2017. Radical Technologies: The Design of Everyday Life. Verso Books.

Harper, R., ed. 2006. Inside the Smart Home. Springer Science \& Business Media.

Hartkopf, V., V. Loftness, A. Mahdavi, S. Lee, and J. Shankavaram. 1997. “An Integrated Approach to Design and Engineering of Intelligent Buildings-The Intelligent Workplace at Carnegie Mellon University." Automation in Construction 6 (5): 401-415.

Heidari, L., M. Younger, G. Chandler, J. Gooch, and P. Schramm. 2017. "Integrating Health into Buildings of the Future.” Journal of Solar Energy Engineering 139 (1): 010802.

Hollands, R. G. 2008. "Will the Real Smart City Please Stand Up? Intelligent, Progressive or Entrepreneurial?" City 12 (3): 303-320.

Joustra, C., and D. H. Yeh. 2014. "Decision Support Systems for Water Reuse in Smart Building Water Cycle Management.” Alternative Water Supply Systems 393: 393-417.

Kuo, C. F. J., C. H. Lin, M. W. Hsu, and M. H. Li. 2017. "Evaluation of Intelligent Green Building Policies in Taiwan Using Fuzzy Analytic Hierarchical Process and Fuzzy Transformation Matrix." Energy and Buildings 139: 146-159.

Lehmann, S. 2016. "Advocacy for the Compact, Mixed-Use and Walkable City: Designing Smart and Climate Resilient Places.” International Journal of Environment and Sustainability (IJES) 5 (2): $1-11$. 
Lilis, G., G. Conus, N. Asadi, and M. Kayal. 2016. "Towards the Next Generation of Intelligent Building: An Assessment Study of Current Automation and Future IoT Based Systems with a Proposal for Transitional Design." Sustainable Cities and Society 28: 473-481.

Lombardi, P., S. Giordano, H. Farouh, and W. Yousef. 2012. "Modelling the Smart City Performance." Innovation: The European Journal of Social Science Research 25 (2): 137-149.

McGlinn, K., E. O'Neill, A. Gibney, D. O'Sullivan, and D. Lewis. 2010. "SimCon: A Tool to Support Rapid Evaluation of Smart Building Application Design Using Context Simulation and Virtual Reality.” J. UCS 16 (15): 1992-2018.

Misuraca, G., D. Broster, and C. Centeno. 2012. "Digital Europe 2030: Designing Scenarios for ICT in Future Governance and Policy Making." Government Information Quarterly 29: S121-S131.

Monfaredzadeh, T., and U. Berardi. 2015. "Beneath the Smart City: Dichotomy between Sustainability and Competitiveness." International Journal of Sustainable Building Technology and Urban Development 6 (3): 140-156.

Mosannenzadeh, F., A. Bisello, R. Vaccaro, V. D’Alonzo, G. W. Hunter, and D. Vettorato. 2017. "Smart Energy CityDevelopment: A Story Told by Urban Planners." Cities (London, England) 64: $54-65$.

Mostashari, A., F. Arnold, M. Mansouri, and M. Finger. 2011. "Cognitive Cities and Intelligent Urban Governance." Network Industries Quarterly 13 (3): 4-7.

Ojasalo, J., and L. Tähtinen. 2017. "Digital Participation in an Open Innovation Platform: An Empirical Study on Smart Cities.” INTED2017 proceedings, Valencia, 10097-10106.

Raj, P., and A. C. Raman. 2015. Intelligent Cities: Enabling Tools and Technology. Florida: CRC Press.

Rocha, P., A. Siddiqui, and M. Stadler. 2015. "Improving Energy Efficiency via Smart Building Energy Management Systems: A Comparison with Policy Measures." Energy and Buildings 88: 203-213.

Roche, S., N. Nabian, K. Kloeckl, and C. Ratti. 2012. "Are 'Smart Cities' Smart Enough.” Global geospatial conference, Québec City, 215-235.

Strengers, Y. 2016. "Envisioning the Smart Home: Reimagining a Smart Energy future." Digital Materialities: Design and Anthropology 61:61-76.

Suryadevara, N. K., S. C. Mukhopadhyay, R. Wang, and R. K. Rayudu. 2013. "Forecasting the Behavior of an Elderly Using Wireless Sensors Data in a Smart Home." Engineering Applications of Artificial Intelligence 26 (10): 2641- 2652.

Turner, J. S. 2016. "Homeostasis is the Key to the Intelligent Building." Intelligent Buildings International 8 (2): 150- 154.

Walters, D. 2011. "Smart Cities, Smart Places, Smart Democracy: Form-Based Codes, Electronic Governance and the Role of Place in Making Smart Cities." Intelligent Buildings International 3 (3): $198-218$.

Wang, X. Y., Z. Peng, X. Q. Yu, J. Zhao, and L. Wang. 2016. "Intelligent Architecture Design and Research Based on Smart City." Mechanics and architectural design: Proceedings of 2016 international conference, Suzhou, Jiangsu, China, 156-161.

Wang, Z., L. Wang, A. I. Dounis, and R. Yang. 2012. "Integration of Plug-in Hybrid Electric Vehicles into Energy and Comfort Management for Smart Building." Energy and Buildings 47: 260-266.

Wong, J. K., H. Li, and S. W. Wang. 2005. "Intelligent Building Research: A Review." Automation in Construction 14 (1): 143-159.

Zhang, D., N. Shah, and L. G. Papageorgiou. 2013. "Efficient Energy Consumption and Operation Management in a Smart Building with Microgrid." Energy Conversion and Management 74: 209222 